\title{
Towards a typology of stop assibilation ${ }^{*}$
}

\author{
T. A. Hall and Silke Hamann \\ University of Leipzig and Zentrum für Allgemeine Sprachwissenschaft \\ hall@rz.uni-leipzig.de and silke@zas.gwz-berlin.de
}

\begin{abstract}
In this article we propose that there are two universal properties for phonological stop assibilations, namely (i) assibilations cannot be triggered by /i/ unless they are also triggered by $/ \mathrm{j} /$, and (ii) voiced stops cannot undergo assibilations unless voiceless ones do. The article presents typological evidence from assibilations in 45 languages supporting both (i) and (ii). It is argued that assibilations are to be captured in the Optimality Theoretic framework by ranking markedness constraints grounded in perception which penalize sequences like [ti] ahead of a faith constraint which militates against the change from /t/ to some sibilant sound. The occurring language types predicted by (i) and (ii) will be shown to involve permutations of the rankings between several different markedness constraints and the one faith constraint. The article demonstrates that there exist several logically possible assibilation types which are ruled out because they would involve illicit rankings.
\end{abstract}

\section{Introduction}

This article examines stop assibilations - defined here as processes which convert a (coronal) stop to a sibilant affricate or fricative before high vocoids, e.g. /t/ is realized as [ts] or [s] before $/ \mathrm{i} /$. We propose two properties for assibilation rules which we claim are universal, namely (i) assibilations cannot be triggered by /i/ unless they are also triggered by $/ \mathrm{j} /$, and (ii) voiced stops cannot undergo assibilations unless voiceless ones do. The descriptive goal of this article is to test these two claims by examining assibilation processes in a large number of typologically diverse languages. Theoretically we propose that assibilations are to be captured in the Optimality Theoretic framework (henceforth OT; Prince \& Smolensky 1993) by ranking phonetically grounded markedness constraints penalizing sequences like [it] ahead of a faith constraint which militates against the change from / $t /$ to some sibilant sound. The occurring language types predicted by the two universal properties for assibilations referred to above will be shown to involve permutations of the rankings between several different markedness constraints and the one faith constraint. A major claim of the present article is that there exist several logically possible assibilation types which can all be ruled out because they would involve illicit rankings.

The present treatment is important for several reasons. First, we provide additional evidence that phonological assibilations can only be adequately explained by appealing to phonetics (see also Clements 1999 and Kim 2001). Our study supplements the aforementioned studies, since neither linguist considers the properties in (i) and (ii). Second, we argue that the markedness constraints which trigger assibilations are based in perception and that they are therefore not speaker-driven. In this respect our treatment differs significantly from traditional markedness constraints in OT, which are typically based in articulation. Third, we show how our analysis of assibilations is superior to the one proposed by Kirchner (1998), who attempts to capture this process with a fortition constraint. Finally, our study shows how the OT framework can capture occurring vs. non-occurring rule types by

We would like to thank Marzena Zygis for comments on an earlier version of this article and to Hristo Velkov, who found a number of the examples presented in $\S 3$. 
appealing to a universal constraint hierarchy among markedness constraints whose universal ranking is based on phonetics (see also Boersma 1998 and Hamann 2003, who propose similar hierarchies).

The article is structured as follows. In $\S 2$ we discuss stop assibilations from the phonetic perspective and show that these processes are characterized by several general properties (based on the findings of Clements 1999 and Kim 2001). In $\S 3$ we discuss the two universal properties for assibilations referred to above and posit a typology of six language types which we show are attested in a number of languages. By contrast, there are at least five logically possible assibilation types that will be shown not to be attested. In $\S 4$ we posit an OT analysis of the typological generalizations presented in $\$ 3$ which accounts for the six occurring assibilation types while simultaneously ruling out the five nonoccurring types. $\S 5$ concludes.

\section{$1 \quad$ Stop assibilations}

In this section we define what we mean by stop assibilation and then present several universal properties for such processes (discussed by Clements 1999 and Kim 2001). ${ }^{1}$

Stop assibilations (or assibilations for short) are defined here as processes whereby stops become sibilant affricates or sibilant fricatives before high vocoids. Three examples of such rules have been presented in (1).

(1) Three examples of assibilation rules:
a. $\mathrm{t} \square \mathrm{s} / \mathrm{i}_{\mathrm{i}}$
Finnish (Kiparsky 1973)
spirantization
b. $\mathrm{t} t \mathrm{t} \square \mathrm{tsts} /$ i $\mathrm{K}$ Korean $(\operatorname{Kim} 2001)$
affrication
c. $\mathrm{t} \square \mathrm{t} \square / \_\mathrm{i} \quad$ West Futuna-Aniwa (Daugherty 1983)
palatalization

We classify the three assibilation processes in (1) according to their output; thus, we call rules like the one in (1a-c) 'spirantizations', 'affrications' and 'palatalizations' respectively. Although we are primarily interested in affrications and spirantizations (because these processes are not as well studied as palatalizations) we include palatalizations in the typology we posit below for three reasons. First, many languages have processes which have as the output either [ts] or [t]]. Second, palatalizations seem to obey the same kinds of generalizations as affrications and spirantizations, namely the two universal properties referred to in $\S 1$. And third, the three processes arguably have the same function of avoiding surface sequences like [ti].

Although processes like the ones in (1) can also affect a velar stop (e.g. in Late Latin $/ \mathrm{k}$ C/ surfaced as [ts dz] before $/ \mathrm{j} /$; Pope 1952) and in some rare languages a labial (e.g. in Lahu labial stops and nasals are affricated before /u/; Mattisoff 1982: 3), we restrict our typology in $\S 3$ and the analysis in $\S 4$ to assibilations which have a coronal stop as the input segment, in particular the input is dental or alveolar, i.e. [+coronal, +anterior] in terms of features.

Assibilations like the ones in (1) can either be lexical or postlexical rules. For example, in Korean (see 1b) assibilation is lexical because it is restricted to applying within a derived environment and does not affect tautomorphemic /ti/, /tDi/ sequences. In Quebec French (Cedegren, Archambault \& Boulianne 1991, Kim 2001) the assibilation rule is

1 In addition to the two studies mentioned above the previous literature on stop assibilations includes Foley $(1973,1977)$ and Bhat (1978). It should be noted that the often cited typological study of Bhat (1978) does not discuss the issues we treat below. 
postlexical because it applies across the board, both within and across words. Since the properties we discuss below hold for postlexical and lexical assibilations we do not see the need to distinguish between the two rule domains. On similar lines we discuss both synchronic rules of assibilation as well as diachronic ones because both processes display the properties we discuss below.

The term 'assibilation' is used here in a very narrow sense since we restrict our discussion below to processes like the ones in (1), which share the following three properties (based on the findings of Foley 1973, 1977, Clements 1999 and Kim 2001):

(2) Three properties of stop assibilations:

a. the trigger is some subset of the high front vocoids (i.e. / i y j/)

b. the output is a sibilant (either an affricate or a fricative)

c. the trigger is to the right of the target

Kim (2001) and Clements (1999) offer a phonetic explanation for the properties of stop assibilation in (2a-c). The creation of sibilants from stops has its phonetic origin in the brief period of turbulence (or 'friction phase') which occurs at the release of a stop into a following high vocoid. Thus, Clements (1999) and Kim (2001) show that stridency is generated when the tongue moves from the oral closure of a coronal stop into the position required for the articulation of a high vocoid (see also Ohala 1983). This phonetic explanation is captured directly in the markedness constraints we propose in $\S 4$.

The properties in (2) are strong cross-linguistic tendencies. In (3) we have listed processes which violate one or more of them:

(3) Exceptions to the properties in (2):
a. $\quad \mathrm{t} \square \mathrm{s} / \ldots \mathrm{i}, \mathrm{u}, \mathrm{e}, \mathrm{o}$
Woleaian (Tawerilmang \& Sohn 1984: 184)
b. $\mathrm{t} \square \square / \mathrm{i}$
Tümpisa Shoshone (Dayley 1989: 407)
c. $\quad \mathrm{td} \square \mathrm{t} \square \mathrm{d} \square / \mathrm{i}$
Pima Bajo (Fernandez 1996: 4)
$\mathrm{t} \square \mathrm{t} \square / \mathrm{i}$
Apalai (Koehn \& Koehn 1986: 120)
$\mathrm{t} \square \mathrm{t} \longrightarrow \mathrm{i}$
Basque (Hualde 1991: 108-109)

In (3a) we have presented an example of a language in which assibilation is not triggered by a subset of the high front vocoids. The process in (3b) is the only example to our knowledge of a process in which a nonsibilant fricative is the output, but which is in line with most of the other properties in (2). Finally, in (3c) we have listed three languages in which the trigger is to the left of the stop (this also holds for $3 b$ ).

In many languages stops change to sibilant affricates or sibilant fricatives but the rules are not conditioned by a vocalic element. Although these processes are often referred to as 'assibilations' in the literature, we exclude them from our analysis because we focus only on processes like the ones in (1) which are triggered by high (front) vocoids. Three examples of the kinds of processes we will not discuss are presented in (4):

(4) Examples of changes excluded by our definition of assibilation:
a. $\mathrm{t} \square \mathrm{ts} / \#$
Old High German (Penzl 1972)
b. t $\square$ ts / $[$ [
Danish (BasbD11 \& Wagner 1985: 67).
c. $\mathrm{td} \square$ ts dz / _ s z ts dz $\square \mathrm{z}, \mathrm{t} \square \mathrm{dz}$
Polish (Rubach 1994) 
The Old High German example in (4a) is a sound change that transpired in the sixth and seventh centuries. ${ }^{2}$ The process in (4b) is apparantly an allophonic one in Modern Danish. The rule in $(4 \mathrm{c})$ is an optional process in Modern Polish.

\section{$1 \quad$ Typology of assibilations}

In this section we present a typology of assibilation rules like the ones in (1) on the basis of our investigation of assibilations in 45 languages (see the appendix for a complete list of the languages discussed in this article and the respective genetic classification). In $\S 3.1$ we posit a set of ten logically possible assibilation types, only five of which we maintain are actually attested. The five nonoccurring types will be shown to be excluded due to two properties of assibilations we propose below. In $\S 3.2$ we present examples of all of the five occurring assibilation types. (A sixth occurring type will be discussed in $\S 4.3$ ).

\subsection{Introduction}

Recall from (2b) that the trigger for stop assibilation is typically some set of the high front vocoids (i.e. the vowel $/ \mathrm{i} /$ and glide $/ \mathrm{j} /$ ). Given the two triggers $/ \mathrm{i} /$ and $/ \mathrm{j} /$ there are four logical assibilations, which we have listed in (5):

(5) a. Assibilation is triggered by $/ \mathrm{i} /$ and $/ \mathrm{j} /$

b. Assibilation is triggered only by $/ \mathrm{j} /$

c. Assibilation is triggered only by /i/

d. Assibilation is triggered by neither $/ \mathrm{i} /$ nor $/ \mathrm{j} /$

The second property we discuss concerns the sounds undergoing assibilations, in particular we investigate the difference between voiceless and voiced stops in the input. Thus, given the two input segments /t/ and /d/, four possible assibilations are summarized in (6):

(6) a. $/ \mathrm{t} /$ and $/ \mathrm{d} /$ assibilate

b. Only /t/ assibilates

c. Only /d/ assibilates

d. Neither $/ \mathrm{t} /$ nor $/ \mathrm{d} /$ assibilate

Combining the eight variables in (5) and (6) yields sixteen logically possible assibilation types. Four of these sixteen combinations involve variable (6d), i.e. alveolar stops do not assibilate at all $(=6 d+5 a, 6 d+5 b, 6 d+5 c, 6 d+5 d)$. We have classified all four of these combinations into one language type, namely type $\mathrm{E}$ (see 7 below). Three of the remaining twelve combinations show assibilation without a high front vocoid trigger (i.e. $5 \mathrm{~d}+6 \mathrm{a}, 5 \mathrm{~d}+6 \mathrm{~b}$, $5 d+6 c)$. Examples for these kinds of assibilations (i.e. those in which the trigger is not some high vocoid) were given under (4). Since these rule types are not topic of the present article we do not include them in our typology in (7). The remaining nine combinations correspond to the additional language types in (7) and (8) (i.e. A-D, F-J). In this typology we have two general categories (to be justified in $\S 3.2$ ), namely assibilation types which are occurring (types A-E) and those which are not (types F-J).

2 In addition to the word-initial context in (4a)/t/ was assibilated to [ts] in other environments as well, e.g. after $/ \mathrm{r} /$ in words like her[ts]a (cf. the English cognate heart). In addition, $/ \mathrm{p} / \mathrm{and} / \mathrm{k} / \mathrm{surfaced}$ as the corresponding affricates. 
(7) Occurring assibilation types:

Language Type assibilating segment(s)

$\begin{array}{llll}\mathrm{A} & / \mathrm{t} \mathrm{d} / & / \mathrm{ij} / & 6 \mathrm{a}+5 \mathrm{a} \\ \mathrm{B} & / \mathrm{t} \mathrm{d} / & / \mathrm{j} / & 6 \mathrm{a}+5 \mathrm{~b} \\ \mathrm{C} & / \mathrm{t} / & / \mathrm{ij} / & 6 \mathrm{~b}+5 \mathrm{a} \\ \mathrm{D} & / \mathrm{t} / & / \mathrm{j} / & 6 \mathrm{~b}+5 \mathrm{~b} \\ \mathrm{E} & \text { none } & / \mathrm{ij} /, / \mathrm{i} /, / \mathrm{j} /, \text {, none } & 6 \mathrm{~d}+(5 \mathrm{a}, 5 \mathrm{~b}, 5 \mathrm{c}, 5 \mathrm{~d})\end{array}$

(8) Nonoccurring assibilation types:

Language Type assibilating segment(s) trigger(s)

$\begin{array}{llll}\mathrm{F} & / \mathrm{t} \mathrm{d} / & / \mathrm{i} / & 6 \mathrm{a}+5 \mathrm{c} \\ \mathrm{G} & / \mathrm{t} / & / \mathrm{i} / & 6 \mathrm{~b}+5 \mathrm{c} \\ \mathrm{H} & / \mathrm{d} / & / \mathrm{ij} / & 6 \mathrm{c}+5 \mathrm{a} \\ \mathrm{I} & / \mathrm{d} / & / \mathrm{j} / & 6 \mathrm{c}+5 \mathrm{~b} \\ \mathrm{~J} & / \mathrm{d} / & / \mathrm{i} / & 6 \mathrm{c}+5 \mathrm{c}\end{array}$

The typology in (7-8) takes all three assibilation types in (1) into consideration, i.e. affrications, spirantizations and palatalizations. Thus, we show below in $\S 3.2$ that these three assibilation types are attested for the occurring types in (7), and none of the three assibilation types is attested in the five languages in (8).

We argue here that the nonoccurring language types in (8) are true 'systematic gaps' whose absense can be accounted for with the following two universal properties of assibilations. $^{3}$

(9) Two additional properties of stop assibilations:

a. Assibilation cannot be triggered by /i/ unless it is also triggered by $/ \mathrm{j} /$.

b. Voiced stops cannot undergo assibilations unless voiceless ones do.

In $\S 3.2$ we present examples of languages corresponding to the various language types in (7), thereby lending support to the two properties in (9). $\$ 4$ we present phonetically grounded constraints which account for why the properties in (9) hold.

We noted above in $\S 2$ that our study is restricted to assibilations in which the input consists of an (oral) stop, but we hypothesize that the same generalizations holds for 'assibilations' in the broad sense of the word. For example, our impressionistic view of velar palatalizations suggests that property (9a) also holds. (9a) may also hold for processes of palatalization in which the input is some sound other than a nonstrident stop, e.g. fricatives like /s z/, as well as nasals and laterals (see also our remarks in $\$ 3.2 .2$ for Baztan Basque). It may even hold for processes not commonly characterized as assibilations, e.g. the change from / $[$ / to [s] before /i, i $\mathrm{j} /$ in Plains Cree (Wolfart 1973: 79). Further research will also determine whether (9a) can be generalized to all gildes and high vowels and not simply /i/ and $/ \mathrm{j} /$. We also hypothesize that (9b) is valid for processes like the ones in (4) above, in which the trigger is not a vocalic element. Further research is therefore required to determine the extent to which (9a) and (9b) hold for other phonological processes.

Property (9a) can be tested by scrutinizing languages with sequences like /tj/ and /ti/ in which assibilation affects / $t /$. Our study is confounded by the fact that in many assibilating languages there is a strict phonotactic restriction prohibiting $/ \mathrm{Cj} /$ sequences (or more

3 Foley $(1973,1977)$ proposes what he seems to consider a universal generalization for assibilations which is equivalent to (9a), but he only discusses examples from English and French in support of it. To our knowledge no one to date has proposed $(9 b)$. 
generally, any sequence of nonsyllabic segments). It is important to stress here that (9a) cannot be refuted with a language which assibilates /t/ before /i/ and which simply does not have any / $\mathrm{tj} /$ sequences. Thus, this example is not Type G, but instead Type C. A similar point can be made with respect to $/ \mathrm{t} /$ and $/ \mathrm{d} / \mathrm{as}$ inputs. Hence, if a language assibilates $/ \mathrm{t} / \mathrm{before} / \mathrm{i} \mathrm{j} /$ then it can only be classified as Type $\mathrm{C}$ if there are / $\mathrm{di} \mathrm{dj} /$ sequences which do not assibilate. If this language has no / $\mathrm{di} \mathrm{dj} /$ sequences to begin with then this language is not Type $\mathrm{C}$, but instead Type A. Type $\mathrm{G}$ and Type $\mathrm{C}$ are illustrated in (10a, b) respectively. The language described above, in which /ti/ assibilates but which does not have / $\mathrm{t} \mathrm{j} /$, is classified as Type $\mathrm{C}$ (see 10c).

a. A nonoccurring assibilation rule (Type $G)$ :

$/ \mathrm{ti} / \square[\mathrm{tsi}]$

$/ \mathrm{tj} / \square[\mathrm{tj}]$

(/di/ does not assibilate)

b. An occurring assibilation rule (Type $\mathrm{C}$ ):

$/ \mathrm{ti} / \square[\mathrm{tsi}]$

$/ \mathrm{tj} / \square[\mathrm{tsj}]$

(/di dj/ do not assibilate)

c. An occurring assibilation rule (Type C):

$/ \mathrm{ti} / \mathrm{Q}[\mathrm{tsi}]$

(/tj/ does not occur; /di/ does not assibilate)

\subsection{The occurring language types}

In this section we present examples from language types A-E. In our typology we present 45 assibilation rules (as defined in \$2) in a typologically and geographically diverse set of languages (see the appendix). Our survey subsumes the three kinds of assibilations in (1). The assibilations listed below include purely allophonic (postlexical) processes, as well as neutralizing and highly morphologized (i.e. lexical) assibilations. Historical processes are included as well. Although our analysis in $\S 4$ is only intended to account for the assibilation of anterior sounds before high front vowels, we have also included below assibilations triggered by other vocalic elements (e.g. high back vowels, mid vowels) because these rules seem to obey the same generalizations in (9).

It will become evident below that there is an unequal distribution among language types, in particular, types $\mathrm{A}, \mathrm{C}$ and $\mathrm{E}$ are represented by many languages whereas only a very small number belong to types $\mathrm{B}$ and $\mathrm{D}$. Among the $\mathrm{A}, \mathrm{C}$ and $\mathrm{E}$ languages it appears that types $\mathrm{A}$ and $\mathrm{E}$ outnumber those of type $\mathrm{C}$. We hypothesize that this unequal distribution is truly systematic and that these patterns would be confirmed by investigating assibilations in additional languages. Since we take the unequal distribution among the various types as systematic and not accidental we discuss a possible reason for it in $\S 4.4$ below.

\subsubsection{Type A}

Examples of Type A languages have been presented in (11). In the second column we list the corresponding rule type.

(11) Type A languages:

a. Quebec French (Cedegren et al. 1991)

b. Kpándo (Vhe) dialect of Gbe (Capo 1991: 99ff.)

c. Nishnaabemwin (Valentine 2001: 86ff.) assibilation type:

affrication

affrication

palatalization 
d. Nyakyusa (Labroussi 1999: 341)

e. Runyoro-Rutooro (Rubongoya 1999: 27)

f. Japanese (Ito[\& Mester 1995)

g. Sorbian (WowcErk 1954: 24-25)

h. Koyra Chiini and Humburi Senni (Heath 1999: 34)

i. Fongbe dialect of Gbe (Lefebre \& Brousseau 2002: 21)

j. Papago (Hale 1965)

k. Taiof (Lynch, Ross \& Crowley 2002: 426f.)

1. Mongo (Spaandonck 1964)

m. Rundi (Spaandonck 1964: 192f.)

n. Ancient Greek (Sommerstein 1973: 15)

o. Plains Cree (Wolfart 1973: 79)

p. Wai Wai (Hawkins 1998: 160)

q. West Greenlandic (Fortescue 1984: 333)

r. Finnish (Sulkala \& Karjalainen 1992)

s. Maori (Bauer 1993: 530f.)

t. Cheyenne (Davis 1962: 36)

u. Samoan (Mosel \& Hovdhaugen 1992: 21)

v. Blackfoot (Frantz 1991: 16, 26)

w. Axininca Campa (Spring 1992: 339)

x. Korean (Kim 2001: 89ff.)

y. Nauran (Kayser 1993: 2)

z. Sonora Yaqui (Dedrick \& Casad 1999: 9)

a'. West Futuna-Aniwa (Dougherty 1983) spirantization

spirantization

affrication, palatalization

palatalization

palatalization

affrication

palatalization

affrication, palatalization

affrication

palatalization

spirantization

affrication

palatalization

affrication

affrication

affrication

affrication, palatalization

affrication

affrication

affrication

affrication

affrication

palatalization

palatalization

A straightforward example of a Type A language is illustrated with the data in (12) from Quebec French (see 11a; data from Kim 2001: 91):

(12) Stop assibilation in Quebec French:

$\begin{array}{lll}\begin{array}{l}\text { Standard French } \\ {[\mathrm{ti}] \mathrm{pe}}\end{array} & \text { Quebec French } & \text { gloss } \\ {[\mathrm{d} \text { isi]pe }} & \text { 'type' } \\ {[\mathrm{dzi}] \mathrm{x}} & \text { 'ten' } \\ {[\mathrm{tj}] \mathrm{ens}} & {[\mathrm{tsj}] \mathrm{ens}} & \text { '(I) hold' } \\ {[\mathrm{dj}] \mathrm{eu}} & {[\mathrm{dzj}] \mathrm{eu}} & \text { 'God' }\end{array}$

The data in (12) show that $/ \mathrm{t} \mathrm{d} /$ assibilate to $[\mathrm{ts} \mathrm{dz}$ ] before $/ \mathrm{i} /$ and $/ \mathrm{j} /$.

A second example of a Type A language is illustrated with the (historical) process of assibilation in the Kpándo (Vhe) dialect of Gbe (see 11b). In the first column the relevant sequences in Proto-Gbe are presented and in the corresponding line of the second column the same sequences in the daughter language Kpándo (Vhe) (data from Capo 1991: 99-100, 104$105) .^{4}$

Throughout this article we use transcriptions which are in accordance with the IPA; hence, in certain examples we have translated the symbols with the equivalent IPA sounds. For example, in (13) Capo's [y] $=[\mathrm{j}]$ and his $\left[\mathrm{t}^{\mathrm{s}} \mathrm{d}^{\mathrm{z}}\right]$ are rendered in (13) as [ts dz]. In the data in (13) and in following tone languages the tones have been omitted. 
(13) Stop assibilation in the Kpándo (Vhe) dialect of Gbe:

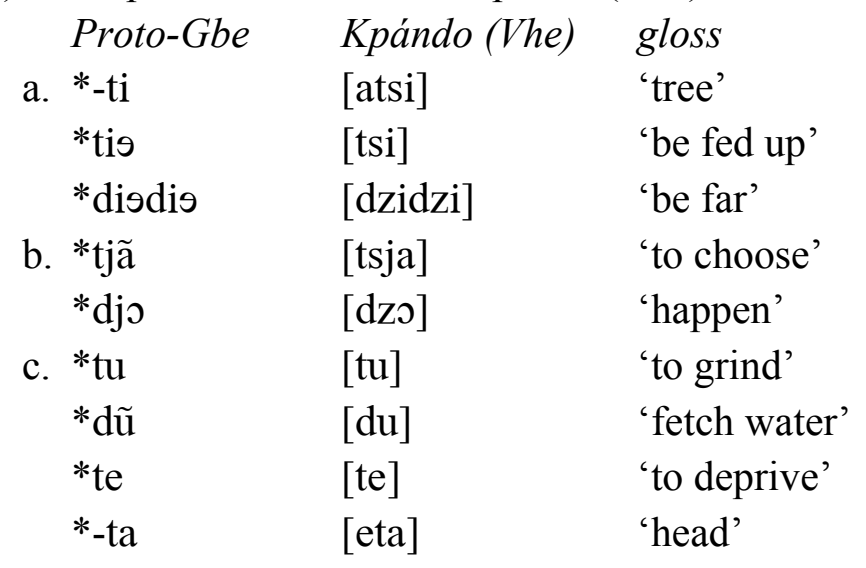

In (13a) it can be observed that $/ \mathrm{t} \mathrm{d} /$ assibilate to [ts $\mathrm{dz}$ ] before $/ \mathrm{i} /$. That the palatal glide $/ \mathrm{j} /$ triggers the same process is shown in (13b). (In the second example in $13 \mathrm{~b}$ the palatal glide $/ \mathrm{j} /$ was deleted after triggering assibilation of the preceding /d/). The remaining data in (13c) show that none of the other vowels in the language triggers stop assibilation.

The Algonquian language Nishnaabemwin in (11c) has a lexical process of palatalization whereby $/ \mathrm{t} \mathrm{d} /$ surface as $[\mathrm{t} \square \mathrm{d} 0]$ before morphemes that start with /i/, / [, and /j/ (Valentine 2001: 86ff.):

(14) Stop palatalization in Nishnaabemwin:

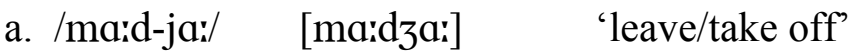

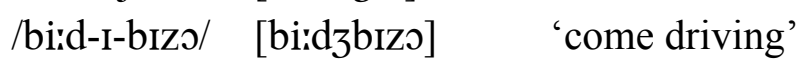
/pilt-70] [pifD] 'grow to such extent'

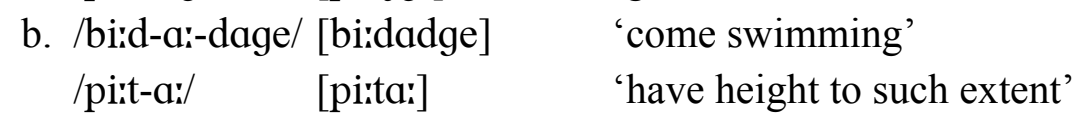

In (14a) examples are given where palatalization occurs (the triggers $/ \mathrm{i} /$ and $/ \mathrm{j} / \mathrm{have}$ been subsequently deleted by syncope, see Valentine 2001), and in (14b) examples with an D-initial morpheme where no palatalization takes place. The Bantu language Nyakyusa in (11d) has a lexical process whereby the causative morphemes $-i-[\mathrm{j}]$ and $-i s y-[[\mathrm{sj}]$ cause spirantization of /t d/ to [s] (Labroussi 1999: 341), e.g. the stems -end-a 'walk' and -and-a 'start' change to [-e[\$-j-a] 'cause to walk', and [and-[sj-a] 'make someone to begin' respectively. RunyoroRutooro in (11e) spirantizes /t/ to [s] and /nd/ to [nz] if affixes are added that begin with /i/, /e/ or /j/ (Rubongoya 1999: 27). In Japanese (11f; Ito \& Mester 1995: 825ff.) /ti/ surfaces as [tDi], e.g. /kat-i/ 'win' (infinitive) is realized as [katDi], and /di/ as [dDi], e.g. in the loanword dilemma as $[\mathrm{d}$ DiLemma]. The high back vowel $[\mathrm{u}](=[\mathrm{Q}]$ in a narrow transcription) causes affrication of the preceding alveolar stop, thus /kat-u/ 'win' (pres.) surfaces as [katsu]. Japanese has no native sequences of $t j$ or $d j$, but loanwords show that $/ \mathrm{j} /$ after alveolar stops also triggers palatalization (Ito \& Mester 1995: 837), e.g. tube [t】u[bu], and juice [dDu[su]. Sorbian (11g; Wowclrk 1954: 24-25) palatalizes /t d/ before /i j/, e.g. hró [d] 'castle' vs. na hró $[d \square] e$ 'on the castle' (from /d+j/), hró[d】]ik 'small castle' (from /d+i/).

Examples (11h-n) are classified as such due to defective distributions of either the glide or the voiced alveolar stop. For example, Koyra Chiini and Humburi Senni (see 11h) underwent a diachronic process whereby both $/ \mathrm{t} d /$ changed to [ $\mathrm{t}$ ] ] before $/ \mathrm{i} /$, e.g. [ $\mathrm{t}$ [i] 'be' in Koyra Chiini and Humburi Senni with [ti] in the neighboring language Koyraboro (Heath 1999: 34). In the Fongbe dialect of Gbe (see 11i) /t d/ assibilate before / $/$ / (Lefebre \& Brousseau 2002: 21), e.g. /ti/ $\square$ [tsi] 'squeeze', /dW [ [dzW ‘be very good' (tones are omitted 
in these examples). Papago (also called O'Odham; see $11 \mathrm{j}$ ) similarly palatalizes /t $\mathrm{d} /$ to [tDdD] before /i u/ (Hale 1965: 299ff). In Taiof (see 11k)/t/ assibilates to [ts] before /i/ and /d/ to [dz] before /i u/ (Lynch, Ross \& Crowley 2002: 426f.). In Mongo and Rundi (see 111, m) the nominalizing suffix $-i$ causes the palatalization of $/ \mathrm{t} /, /{ }^{\mathrm{n}} \mathrm{d} /($ and $\mathrm{n}$ ) (Spaandonck 1964: 192), e.g. Mongo /-lot-/ 'flee' vs. [-lotsi] 'fugitive', /-kDnd-/ 'go' vs. [-kDndzi] 'traveller'. In Ancient Greek (see 11n)/t d/ spirantize to [s] in the context V_ iV (Sommerstein 1973: 15), e.g. [plûtros] 'wealth' vs. [plú[sios] 'wealthy'. (No examples are provided with $a / j /$ in the assibilation context).

In Plains Cree in (11o) / $/$ / assibilates before $/ \mathrm{i}, \mathrm{i} \square$ and before the palatal glide (Wolfart 1973: 79). The output of this assibilation is a sound which ranges from 'a blade-alveolar to a dorso-laminal affricate'. Since Plains Cree has no /d/ which could potentially assibilate we classify it as a Type A language. The situation is the same in the Amazonian language Wai Wai in (see 11p), which has a lexical process of palatalizing $/ \mathrm{t} / \mathrm{t}[\mathrm{t}]$, e.g. $/ \mathrm{t}+\mathrm{irko} /$ [tDirko]'fix/make it' (Hawkins 1998: 160), but there is no /d/ which could potentially assibilate. Wai Wai has a glide /j/, but this sound cannot occur after/t/ (Hawkins 1998: 150).

In the final eleven languages (see 11q-a') there is neither a /d/ which could potentially assibilate, nor a $/ \mathrm{j} /$ which could potentially serve as the trigger. For example, in West Greenlandic (see 11q) singleton and geminate /t/ are assibilated to [ts] in all contexts but this language has no /d/, and /j/ never surfaces after alveolar stops (see Fortescue 1984: 335). In Finnish (11r) there is a lexical rule spirantizing / $t /$ in stems that end in -te before the nominative morpheme $-i$ and the plural morpheme $-i$, e.g. sute $v s$. susi 'wolf (ess. - nom.)' (Sulkala \& Karjalainen 1992). Finnish has no j-initial morphemes to trigger a similar change, and also no d that could undergo spirantization. Both Maori (see 11s; Bauer 1993: 530f.) and Cheyenne (11t) have assibilations triggered by /i/, e.g. /t/ assibilates to [ts] in the former language (with an optional realization as [t[]), e.g. iti 'small' is pronounced as [itsi] or [itDi]. In Samoan (11u), /t/ is affricated to [ts] before /i/ (Mosel \& Hovdhaugen 1992: 20). NeitherMaori, Cheyenne, nor Samoan have /d/ or a palatal glide. Based on alternations between [t] and [ts] Frantz (1991: 25) posits the rule ' $t \square$ ts / _ i' for Blackfoot (see 11v). Frantz (1991: 16) writes that "the sequence $t i$ never occurs in Blackfoot; whenever we would expect $t i$, we find instead $t s i$ ". In Axininca Campa (see $11 \mathrm{w}$ ) the morphologicallyconditioned process of assibilation (referred to by Spring 1992: 339 as 'affrication') is only triggered by certain /i/-initial suffixes, e.g. the non-future tense marker /i/, e.g. /no-kant-i/ $\square$ [nokantsi] 'I said'. However, Spring does not report that assibilation is triggered by any $/ \mathrm{j} /-$ initial morphemes. In Korean (see 11x), like Axininca Campa, assibilation is a derived environment rule which is triggered by suffixes beginning with /i/ (see Kim 2001), e.g. before the nominative suffix /i/ in /mat-i/ $\square$ [madzi] 'first child' and before the adverbial suffix /i/ in $/ \mathrm{kat}^{\mathrm{h}}-\mathrm{i} / \mathrm{C}$ [kats $\left.{ }^{\mathrm{h}}-\mathrm{i}\right]$ 'together'. ${ }^{6}$ Kim lists no /j/-initial suffixes which could potentially trigger the rule. In Nauruan (see 11y; Kayser 1993: 2) there is an apparently allophonic rule which converts /t/ to [ts] (or [dz]); according to Kayser (1993) this language does not have /d/, nor does $/ \mathrm{j} /$ occur before $/ \mathrm{t} /$. In the Uto-Aztecan language Sonora Yaqui (see $11 \mathrm{z}$ ) $/ \mathrm{t} /$ is palatalized to [t]] if followed by an /i/-initial morpheme (Dedrick \& Casad 1999: 9). This language has neither /d/ nor a palatal glide. A purely allophonic rule converting /t/ to [t] (or [dD]) before /i/ holds in West Futuna-Aniwa (see 11a'; Dougherty 1983).

We would like to thank Fernando Zuñiga for bringing the Blackfoot data to our attention.

In the first example cited above the effects of an independent allophonic process of intervocalic voicing can be observed. 


\subsubsection{Type B}

Type A languages can be contrasted with Type B languages, in which only the palatal glide but not /i/ triggers the rule. Four examples of Type B languages have been provided in (15):

(15) Type B languages:

a. Romanian (Chitoran 2001)

b. West Slavic (Carlton 1990)

c. Sanskrit (Misra 1967: 142)

d. Latvian (Forssman 2001: 97) assibilation type:

affrication, spirantization

affrication, spirantization

palatalization

palatalization

Stop assibilation in Romanian (see 15a) is illustrated with the examples in (16) (from Chitoran 2001: 187):

(16) Stop assibilation in Romanian:

$\begin{array}{llll}\text { [munte] } & \text { 'mountain' } & \text { [munts[ } & \text { 'mountains' } \\ \text { [soldat }] & \text { 'soldier' } & \text { [soldats }[ & \text { 'soldiers' } \\ \text { [brad] } & \text { 'fir tree' } & {[\text { braz[ }]} & \text { 'fir trees' }\end{array}$

The effects of the rule can be observed in the second column, in which it is shown that $/ \mathrm{t} /$ assibilates to the affricate [ts] when it bears the plural marker of secondary palatalization and that $/ \mathrm{d} /$ spirantizes to $[\mathrm{z}]$ in the same context. ${ }^{7}$ By contrast, Chitoran (2001) lists no examples in which stop assibilation is triggered by [i].

The West Slavic example in (15b) requires some comment. According to Carlton (1990: 114) Proto-Slavic *t and *d assibilated in the various daughter languages before $* \mathrm{j}$, e.g. in West Slavic *t surfaced as [ts] while *d surfaced in Polish and Slovak as [d]. We assume that affrication and spirantization were triggered by $/ \mathrm{j} /$, which was subsequently deleted. (Although no examples are provided for $*_{\mathrm{t}}$ and $*_{\mathrm{d}}$ before $*_{\mathrm{i}}$ the discussion in Carleton implies that assibilation does not occur in this context). In Modern Slovak and Polish it is usually assumed that there is a morphologically-conditioned rule (called Iotation), which converts /t d/ to [ts dz] before /j/ only (Rubach 1993: 117ff.).

According to Misra (1967: 142) in Sanskrit (i.e. Old Indo-Aryan)/tj dj/ developed into geminate post-alveolar affricates, e.g. Sanskrit/satja/ 'truth' and /vidjut/ 'lightning' were later realized as $/ \mathrm{sattla} /$ and $/ \mathrm{bidd} \square \mathrm{i} /$ respectively. Significantly, this change was only triggered by the palatal glide and not by /i/. In Latvian (Forssman 2001: 97) [t]dD] derive historically from $/ \mathrm{tj}$ dj/, e.g. [latদla] 'bear (gen. sg.) (from *latsją which presumably derives from $/ \mathrm{tj} /$ ).

It needs to be stressed here that we have limited our typology to those processes which have an oral stop as an input. If assibilations were also to subsume rules which have nasal consonants (and or laterals) as the input then the Baztan dialect of Basque would be classified as Type $\mathrm{B} / \mathrm{D}$, since in that language /n $1 /$ palatalize to [0 ] ] after the glide /j/ but not after the vowel /i/ (see Hualde 1991: 114ff.).

\subsubsection{Type C}

Type $\mathrm{C}$ languages (in which / $/ \mathrm{t} /$ assibilates before $/ \mathrm{i} /$ and $/ \mathrm{j} /$ ) are listed in (17). It can be observed below that there are no examples of palatalizations among the Type $\mathrm{C}$ languages. At this point we assume that this gap is purely acidental.

7 Chitoran (2001: 185ff.) treats the process of stop assibilation in (16) as a part of a larger process she calls 'palatalization', which shifts the place of articulation for other segment types, e.g. /s/ surfaces as [] when secondarily palatalized. 
(17) Type C languages:

a. Hittite (Kimball 1999: 287ff.)

b. Dutch (Booij 1995: 79f.)

c. Italian dialects (Tuttle 1997: 26f., Cordin 1997: 261)

d. Shona (Brauner 1995: 13)

e. Woleaian (Tawerilmang \& Sohn 1984: 184)

f. Kosraean (Lee \& Wang 1984: 406)

g. Solomon Islands languages (Tryon \& Hackman 1983: 77)

h. Ambae (Hyslop 2001: 16-17)

i. Tawala (Ezard 1997: 29f.)

j. 'Ala'ala (Lynch, Ross \& Crowley 2002: 347f)

k. Arosi (Lynch, Ross \& Crowley 2002: 562)

1. Turkana (Dimmendaal 1983: 8-9) assibilation type:

affrication

affrication, spirantization

palatalization

affrication, spirantization

spirantization

spirantization

affrication, spirantization

spirantization

spirantization

spirantization

spirantization

spirantization

In all of the Type $C$ languages in our survey but three (i.e. Hittite, $17 \mathrm{a}$, Dutch, $17 \mathrm{~b}$, and some Italian dialects, $17 \mathrm{c}$ ) $/ \mathrm{t} /$ assibilates before $/ \mathrm{i} /$, but $/ \mathrm{j} /$ either does not occur at all or it does exist but it never surfaces after $/ \mathrm{t} /$ (as in 10c). As we noted above in $\$ 3.1$ the preponderance of (10c) examples over (10b) is simply indicative of the fact that many assibilating languages like the ones discussed below ban $\mathrm{Cj}$ sequences.

According to Kimball (1999: 287ff.) Indo-European *t assibilated to an affricate before /i j/ in Hittite (see 17a), e.g. the suffix *-tjo- in [hantetsja] 'last', [hahts] 'in front' (from an earlier form with a final/i/). Kimball (1999: 291-292) also discusses whether or not Indo-European $* \mathrm{~d}$ assibilated as well and concludes that the few examples which seem to suggest this development have other explanations.

Dutch (see 17b) is a language with a lexical rule that turns /t/ into [s] or [ts] after certain (Latinate) suffixes which start with [i] or [j] (Booij 1995: 79f.). These morphemes are

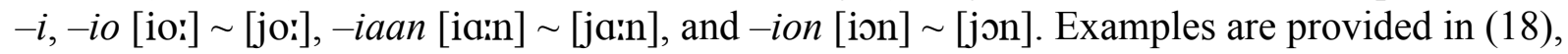
in which $/ \mathrm{t} /$ surfaces as $[\mathrm{s}]$ after a consonant (see 18a) and as [ts] or [s] intervocalically (see $18 b)$.

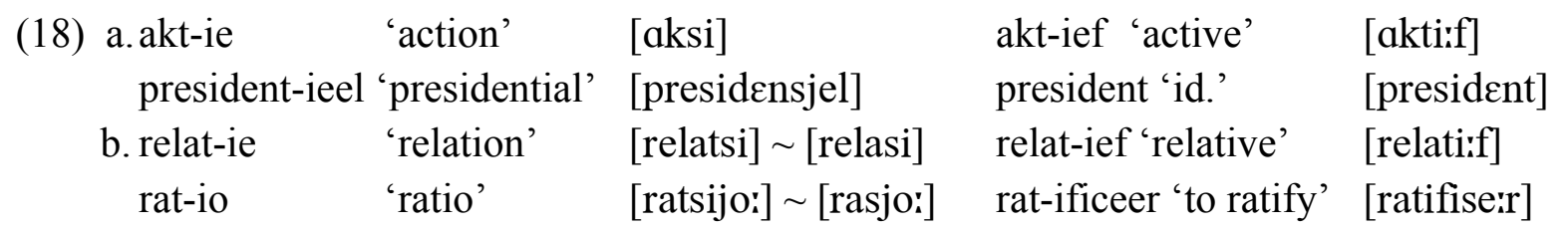

In the Northern Venetian dialect of Italian (see $17 \mathrm{c}$ ), / $\mathrm{t} /$ palatalized before $/ \mathrm{i} /$ and $/ \mathrm{j} /$. Thus the Old Venetian form [tiol] 'he removes' is now realized as [t[ol], and [tj[ni] 'hold' as [tleD] (Tuttle 1997: 26). Furthermore, Tuttle (1997: 30) reports that the inflectional plural marker $-i$, which became a glide before vowels in rapid speech and was later lost, palatalized the preceding / $\mathrm{t} /$ in Ticino. Examples are quanti 'how much' (pl.) which is realized as

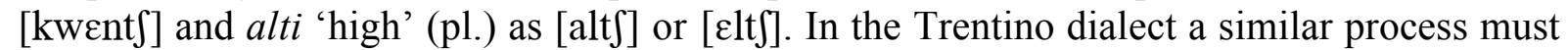
have taken place, as the example gatti 'cats' [Dat]] from Cordin (1997: 261) suggests.

Assibilation as diachronic process occurred in the development of Shona (see 17d), where Proto-Bantu /ti/ changed to [tsi] after a vowel and to [si] word-initally (Brauner 1995: 13), see (19). 
(19) Stop assibilation and spirantization in Shona:

$\begin{array}{llll}\text { Proto-Bantu } & \text { gloss } & \text { Shona } & \text { gloss } \\ \text { *-tima } & \text { 'displant' } & \text { [-sima] } & \text { 'transplant' } \\ \text { *piti } & \text { 'hyena' } & \text { [sDitsi] } & \text { 'spotted hyena' }\end{array}$

Shona has a voiced stop /d/ (written as 'dh') in loanwords only, e.g. dhora 'dollar', which is not reported to undergo assibilation (Brauner 1995: 10).

Historical assibilations transpired in a number of Austronesian languages in the Oceanic branch (17e-i). For example in Woleaian (see 17e) there was a diachronic process of assibilation which converted Proto-Oceanic *t into [s] before /i u e o/, as in (20) (Tawerilmang \& Sohn 1984: 184):

(20) Proto-Oceanic

*tama

* पatop

*mate

*tika

* Datun

$\begin{array}{ll} & \text { Woleaian } \\ > & \text { tama } \\ > & \text { aso } \\ > & \text { mase } \\ > & \text { sixa } \\ > & \text { asu }\end{array}$

A similar process transpired in the history of Kosraean (see 17f; Lee \& Wang 1984: 406). According to this source, Proto-Oceanic $* t$ surfaced as $[\mathrm{s}]$ before front vowels (but $* \mathrm{~d}$ was not affected). Tryon \& Hackman (1983: 77) note that an assibilation affected Proto-Oceanic *t in the Solomon Islands languages (17f) Vaghua, Varisi, Ririo and Sengga (also known as Central-East Choiseul), all spoken on the island of Choiseul. In the first of these languages the assibilation was an affrication which went into effect before high vowels and in the final three it was an assibilation triggered by /i/. In all of these languages Proto-Oceanic $* d$ surfaced as [r]. According to Hyslop (2001: 26) in all dialects of Ambae (see 17h; Oceanic, Vanuatu) except for Lolokaro a fricative [s] developed from Proto-Oceanic /t/ before /i/, as in (21):

(21) Stop spirantization in Ambae:

$\begin{array}{lll}\text { Proto-Oceanic } & \text { Ambae } & \text { gloss } \\ *_{\text {tibo- }}> & \text { sibo- } & \text { 'self' } \\ \text { *pati }>^{*}>\text { Desi } & \text { 'four' }\end{array}$

Proto-Oceanic had a /d/ and a /j/, but allowed only CV syllables (Lynch, Ross \& Crowley 2002: 65). Proto-Oceanic $* d$ became a prenasalized voiced alveolar stop $\left[{ }^{\mathrm{n}} \mathrm{d}\right]$ in the dialects of Ambae in all contexts, e.g. didiu 'ant' is realized as [ $\left.{ }^{\mathrm{n}} \mathrm{d} \mathrm{C}^{\mathrm{D}} \mathrm{di} \square\right]$ ] (Hyslop 2001: 29). Tawala (see 17i; Ezard 1997) underwent a diachronic process whereby /t/ was fricativized to [s] before the high front vowel /i/. According to Ezard (1997: 30), "the dialect variation of some forms reflect this rule", e.g. [emota] [emosi] 'one', [hota] [hosi] 'only'. By contrast, /d/ remained unchanged, cf. badila [badila] 'the name of a native almond'. Tawala has also a palatal glide, but does not allow other than $(\mathrm{C}) \mathrm{V}$ syllables, thus a potential sequence tjV to trigger spirantization does not occur.

Synchronic processes of assibilation are also common in Oceanic languages. For example, in 'Ala'ala (see 17j; Lynch, Ross \& Crowley 2002: 347f) spirantization creates the allophone [s] from /t/ before /i/, e.g. /Diti/ 'upward' surfaces as [Disi] but /aDate/ 'women' as [aロate]. /d/ remains unchanged in this language, e.g. /nodi/ surfaces as [nodi] 'coughs' (Lynch et al. 2002: 348). 'Ala'ala is not reported to have a palatal glide. In Arosi (see 17k) the contrast between /t/ and /s/ is neutralized to [s] before /i/ (Lynch, Ross \& Crowley 2002: 562). 
In Turkana (see 171) Dimmendaal (1983: 8-9) reports that /t/ (but not /d/) spirantizes to [s] before suffixes beginning with a front vowel, e.g. /a-k-mat/ 'to drink' vs. /a-mat- $\square$ [ [amas[] 'I am drinking'. (Although this language has a $/ \mathrm{j} /$, no examples are provided with a suffix beginning with $/ \mathrm{j} /$ which occurs after a stem ending in $/ \mathrm{t} /$ ).

\subsubsection{Type D}

In Type D languages /t/ assibilates before [j]. Examples are provided in (22). ${ }^{8}$ The lack of Type D languages which exhibit spirantization and palatalization is probably accidental, due to the small number of languages belonging to this category.

(22) Type D languages:

a. Latin (Pope 1952)

b. German (Hall 2003) assibilation type:

affrication

affrication

Stop assibilation in Latin is illustrated in (23). According to Pope (1952: 129ff.) and Jacobs (1989: 117ff) /t/ affricated to [ts] before $/ \mathrm{j} /$ in the course of Late Latin. Pope (1952: 129) writes that the change is attested as early as the fourth century. This development is illustrated with the examples in (23) from Pope (1952: 130):

(23) Stop assibilation in Late Latin:

$\begin{array}{llll}* \text { fortja } & > & * \text { fortsja } & \text { 'force' } \\ \text { *faktjone } & > & \text { fatsun } & \text { 'manner' }\end{array}$

In contrast to the assibilation in (23), Pope (1952: 129) notes that the same process did not affect $/ \mathrm{dj} / .^{9}$

Stop assibilation in German is illustrated with the data in (24) (from Hall 2003). That this is a regular process of the language and not simply an inheritance from Latin is discussed in that source.

(24) Stop assibilation in German:

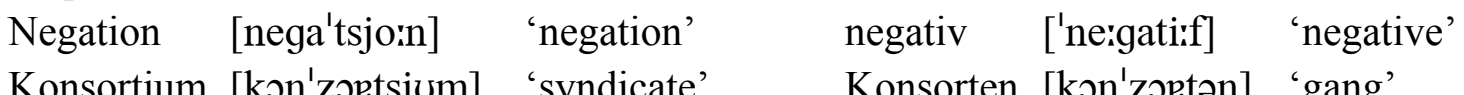

In these examples we can observe an assibilation of $/ \mathrm{t} /$ to [ts] before $/ \mathrm{j} /$. The example negativ in the second column is important because it shows that the rule is not triggered by the vowel /i/. Examples like Studium [Ztudj] $\square \mathrm{m}]$ 'studies (sg.)' show that assibilation only affects /t/ and $\operatorname{not} / \mathrm{d} /$.

\subsubsection{Type E}

Type E languages are those in which no segments assibilate. Our main descriptive goal in this article has been to find examples of languages with assibilations, so we do not claim to have an extensive list of Type E languages. However, we do maintain that languages belonging to Type E are extremely common. One example of a Type E language is Chamorro (see 25a). According to Topping's (1973) description of the phonology there are no processes in this

8 An additional example of a Type D language may be certain dialects of Albanian. Buchholz \& Fiedler (1987: 38) note that /tj/ surfaces as [ts] in Central Albanian, but they write that this only occurs in certain words.

9 Word-initial /dj/ surfaced first as a voiced palatal stop [ [] and then later on as [dD]; intervocalically / $\mathrm{dj} /$ went to [] and then to [j]; see also Sommer (1948), who agrees that there was a stage in the history of Latin with []). 
language resembling assibilations as defined in $\S 2$. Although Lahu (see $25 b$ ) is one of the few languages in which labials assibilate (recall §2), this language has no process of assibilation in which the input is a coronal stop (Matisoff 1982). We speculate here that certain language families (and possible linguistic areas) tend not to assibilate $/ \mathrm{t} d /$. One example is illustrated by the indiginous languages of Australia (see Dixon 1980 for a survey). Two examples of Australian languages are provided in $(25 \mathrm{c}, \mathrm{d})$. In neither of these descriptions is reference made to assibilation processes.

(25) Type E languages:

a. Chamorro (Topping 1973)

b. Lahu (Matisoff 1982)

c. Nhanda (Blevins 2001)

d. Gaagudju (Harvey 2002)

A possible reason for the lack of spirantizations and affrications in Australian languages might be that the typical Australian language does not have fricatives or affricates (i.e. [ts]). Note that the ban on sounds like [s] and [ts] in typical Australian languages is also enforced at the level of grammar where allophonic rules go into effect (i.e. postlexically).

\section{$1 \quad$ A formal analysis}

In this section we present a formal OT analysis of the typology in $§ 3.2$. Specifically, we show that assibilation is captured by ranking one or more markedness constraint ahead of a faith constraint which militates against changing the feature [strident]. It will be argued below that the markedness constraints required to capture assibilations are grounded in phonetics and that a (phonetically motivated) universal ranking can be posited which rules out all of the nonoccurring language types in (8). The occurring language types in (7) (discussed in §3.2) will be shown to involve the ranking of the one faith constraint with respect to the universal ranking for markedness constraints. In the following analysis we only restrict ourselves to the assibilation of alveolar stops before high fronts vocoids. Other kinds of assibilation processes (e.g. those in which the process is triggered by other vowels, those in which velars form the input) require markedness (and/or faith) constraints not discussed below.

\subsection{Phonetically grounded markedness constraints}

As described in $\S 2$, the release of an alveolar stop into a high front vocoid causes a period of turbulence (or 'friction phase'; see Clements 1999, Kim 2001) which is significantly greater than the friction phase of the same stop which is released into a non-high and/or non-front vocoid. The period of turbulent air stream that emerges at the release of an alveolar stop into a high front vocoid has acoustically the same characteristics as the friction noise caused by an alveolar strident fricative. For a listener it is therefore difficult not to perceive the friction phase of the stop-vocoid sequence as a separate fricative. This is the function of the (perceptual) markedness constraint $* \mathrm{tj}$ in $(26 \mathrm{a})$.

(26) Two markedness constraints:

a. * $\mathrm{tj}_{\mathrm{j}}$ : The sequence $/ \mathrm{tj} /$ cannot be perceived as such/without a fricative.

b. *ti: The sequence /ti/ cannot be perceived as such.

Markedness constraints that refer to perceptual or auditory information is not new in phonology; see, for instance, Flemming's (1995) MinDist constraints and Steriade's (2001) correpsondence constraints that are based on a perceptual map (the so-called 'P-map'). 
Kirchner (1998: 117ff.) also posits perceptually-based markedness constraints and argues that they account for assibilations. Kirchner's approach to assibilation will be compared to the present proposal at the end of this section.

The same turbulence that is present in a sequence / $\mathrm{tj} / \mathrm{can}$ also be observed in a / $\mathrm{t} /$ sequence, since the glide $/ \mathrm{j} /$ and the high front vowel $/ \mathrm{i} /$ do not differ articulatorily. Again, the listener is likely to confuse this friction noise with the presence of a fricative segment. We capture this fact with the perceptual markedness constraint $*$ ti in (26b).

However, the total duration of the vowel $/ \mathrm{i} /$ is by far longer than that of the glide $/ \mathrm{j} /$, see Catford (2001: 68), who refers to $/ \mathrm{j} /$ as an 'ultra-short' /i/. The same duration of friction seems therefore shorter in a $/ \mathrm{t} \mathrm{i} /$ sequence than in a $/ \mathrm{tj} /$ sequence. As a consequence, the friction phase in a $/ \mathrm{t} i$ / sequence is less likely to be perceived as a full segment than the same friction phase in a $/ \mathrm{t} \mathrm{j} /$ sequence. This can be expressed as universal ranking between the two markedness constraints in (27). Similar universal constraint rankings grounded in phonetics are proposed by Boersma (1998) and Hamann (2003). ${ }^{10}$

(27) A universal ranking:

$* \mathrm{tj} \gg * \mathrm{ti}$

An argument that the length of the frication phase is perceived in relation to the overall duration of the sequence is illustrated by assibilation in Finnic. Here the / $t$ / was fricativized to [s] before a high front vowel, but the geminate /tt/ remained unchanged (Posti 1954: 51). This can be explained by the fact that the friction phase is perceived as longer if it follows a singleton than if it follows a geminate plosive.

In $\S 3$ it was shown that languages differ in the voicing of the stops that undergo assibilation. For the voiced stops, the two constraints $*$ dj and $*$ di can be stated (see 28 ). Like the constraints in (26) the ones in (28) express the perceptual markedness of the relevant sequences:

(28) Two markedness constraints:

a. *dj: The sequence / $\mathrm{dj} /$ cannot be perceived as such.

b. *di: The sequence /di/ cannot be perceived as such.

Since the duration of the vowel $/ \mathrm{i} /$ and the glide $/ \mathrm{j} /$ influences the perception of the friction phase for both voiced and voiceless stops in the same way, the universal constraint ranking in (29) is stated.

(29) A universal ranking:

$* \mathrm{dj} \gg *$ di

In contrast to sequences of voiceless stop plus glide $/ \mathrm{j} /$ or vowel $/ \mathrm{i} /$, sequences with voiced stops generally show less friction. This is due to two factors. First, the vibrating vocal cords of the voiced stop allow less air to build up behind the constriction in the vocal tract than when the vocal cords are open for the voiceless stops. As a consequence, there is less air pressure at the release of the voiced stop and thus less frication noise generated. Secondly, the

10 Contrary to the present analysis, both Boersma (1998) and Hamann (2003) pose underlying perceptual representations and a distinction between production and perception grammar. The OT production grammar contains perceptual faithfulness constraints and articulatory markedness constraints. An example for the latter are *DISTANCE constraints (Boersma 1998: 150, Hamann 2003: 172), which refer to the articulatory distance between different positions of an articulator, and which can be universally ranked as *DISTANCE $(\mathrm{x}, \mathrm{z}) » *$ DistancE $(\mathrm{x}, \mathrm{y})$ if $(\mathrm{z}-\mathrm{x})>(\mathrm{y}-\mathrm{x})$. 
voicing of the vocal folds produces a sound which masks the frication noise, as illustrated by Catford (2001: 63) in his excersise on voiced and voiceless [i]: "As soon as you devoice [i] the hissing noise of turbulent airflow can be heard."

Taking these aerodynamic and acoustic observations into account, the constraint $*_{t j}$ has to be ranked above its counterpart for the voiced stop, ${ }^{*} \mathrm{dj}$, and $*$ ti similarly needs to outrank *di. It is not clear whether the friction noise is stronger in $/ \mathrm{ti} /$ sequences than $\mathrm{in} / \mathrm{dj} /$ sequences. We therefore suggest that the two constraints $*$ ti and $* \mathrm{dj}$ are not universally ranked with respect to each other. In sum, the two constraint hierarchies from (27) and (29) produce the following universal ranking:

$$
\begin{aligned}
& \text { A universal ranking: } \\
& *{ }_{\mathrm{tj}} »\left\{*_{\mathrm{ti}},{ }_{\mathrm{dj}}\right\} » * \mathrm{di}
\end{aligned}
$$

In addition to the four markedness constraints in (30), one could posit additional constraints militating against the perception of affricates, namely $*$ tsj, $*$ tsi, $* \mathrm{dsj}$, and $*$ dsi. The consonantal sequences referred to in these constraints include an affricate, which by definition has a fricative release. It is therefore not difficult to perceive these sequences properly, since the duration of the friction noise is long enough to be perceived as the fricative release of an affricate. Kim's data (2001: 96ff.) on the length of friction noise in Korean support this point: the friction phase in the (bimorphemic) word [matsi] 'first child' (= [madzi] in a narrow transcription) is on average $69.3 \mathrm{~ms}$ long, more than twice as long as the friction phase in the (monomorphemic) word [mati] 'knot'. We can conclude from this that the constraints militating against sequences of an affricate and a high vocoid are universally lower-ranked than the constraints against sequences of a stop and a high vocoid. As the constraints against affricates are not relevant for the following analyses, we will ignore them.

In sum, the markedness constraints posited above are based on the listener's inclination to parse the perceived friction noise as a separate segment. This idea differs significantly from traditional markedness constraints in OT which are speaker-driven. In Kirchner's (1998) effort-based account of lenition processes, for instance, a LAZY constraint is invoked, which militates against too much effort on the part of the speaker. As Kirchner himself shows (1998: 116ff.), the LAZY constraint alone is not sufficient to account for assibilation processes, since every assibilated output involves more articulatory effort than a non-assibilated one. To solve this problem, a so-called fortition constraint is introduced, "which serve[s] to enhance the salience and robustness of perceptual distinctions" (Kirchner 1998: 26). According to Kirchner (p. 117), a sequence such as /ti/ is automatically produced with some friction, thus possible output candidates for $/ \mathrm{ti} /$ are only [ $\left.\mathrm{t}^{\mathrm{s}} \mathrm{i}\right]$ (with a weakly fricated release) and [tsi]. The newly introduced and highly-ranked fortition constraint $*[+$ fricated release, - strident $]$, requiring fricated releases to be strident, then selects the candidate [tsi] as the winner, because it has a strident release.

In Kirchner's approach the speaker thus actively decides for the strident output [tsi] to "enhance the salience and robustness of perceptual distinctions", as the definition of fortition constraints implies. However, it is not clear from Kirchner's treatment which perceptual distinction is meant to be enhanced by this output. In [tsi] the friction is without question more salient than in $\left[\mathrm{t}^{\mathrm{s}} \mathrm{i}\right]$, but why should the output be maximally salient with respect to friction if the input has no friction at all? A major drawback of this account is that the most faithful candidate [ti] is excluded from Kirchner's OT grammar, though it should be the winning candidate according to the constraints and rankings he proposes. Furthermore, Kirchner's constraint *[+fricated release, - strident] forces the speaker to make a categorical change from a stop to an affricate articulation. This is not desirable and also not necessary, as 
the present approach to assibilation shows: not the exact nature of the speaker's articulation is of importance, but the perception of the listener.

\subsection{An OT analysis}

The typology we present below relies on the interaction between the universal ranking of the four markedness constraints in (30) with the following faith constraint:

$$
\begin{aligned}
& \text { A faith constraint: } \\
& \text { IDENT-[STRID] }
\end{aligned}
$$

The faith constraint in (31) belongs to the IDENT family; it penalizes the change from nonstrident (e.g. /t/) to strident (i.e. [ts], [s], or [t]]). We assume, following several authors, e.g. Jakobson et al. (1952), LaCharité (1993), Rubach (1994), Clements (1999) and Kehrein (2002), that stops differ from the corresponding affricates in terms of the feature [strident]. According to this view a stop like /t/ is [-strident] and an affricate like /ts/ is [+strident]. The analysis of any assibilation process requires that some markedness constraint(s) be ranked ahead of the faith constraint in (31). This point is illustrated in the tableau in (32), in which the change from /atia/ to [atsia] is shown:

\begin{tabular}{r||c|c|} 
/atia/ $\square$ [atsia]: \\
/atia/ & $*$ ti & IDENT-STRI \\
\hline \hline [atia] & $* !$ & \\
\hline$[$ atsia] & & $*$ \\
\hline
\end{tabular}

In the analysis that follows we do not distinguish between the three outputs of the assibilation processes in (1), i.e. spirantization with [s], affrication with [ts] and palatalization with [t]]. Instead we only discuss the manner change of stop to some strident sound (indicated as [ts] in the following tableaux) without specifying the exact phonetic realization. The different outputs (i.e. [ts] vs. [s] vs. [t]]) require additional constraints which are not important for capturing the typology in $\$ 3.2$.

Given the universal markedness constraint hierarchy in (30) the process of assibilation is captured by ranking at least one of these constraints ahead of the IDENT constraint in (31). This ranking is illustrated in (33-36) for a Type A language (e.g. Quebec French). In these tableaux the only crucial ranking is that all four of the markedness constraints outrank the one faith constraint. Evidence for the ranking among the markedness constraints (e.g. *tj $» *$ ti) was discussed in (30) above. It is shown below how these rankings rule out the non-occurring language types.

/atja/ in Type A languages:

a.

\begin{tabular}{r||c|c:c|c|c|} 
/atja/ & $* \mathrm{tj}$ & $* \mathrm{ti}$ & $* \mathrm{dj}$ & $* \mathrm{di}$ & IDENT-STRI \\
\hline$[$ atja] & $* !$ & & & & \\
\hline$[$ atsja] & & & & & $*$ \\
\hline
\end{tabular}

(34) /atia/ in Type A languages:

\begin{tabular}{rr||c|c:c|c|c|} 
& /atia/ & $* \mathrm{tj}$ & $* \mathrm{ti}$ & $* \mathrm{dj}$ & $* \mathrm{di}$ & IDENT-STRI \\
$\mathrm{a}$ & [atia] & & $* !$ & & & \\
b. & & & & & $*$ \\
\hline
\end{tabular}


/adja/ in Type A languages:

a.

\begin{tabular}{r||c|c:c|c|c|} 
/adja/ & $* \mathrm{tj}$ & $* \mathrm{ti}$ & $* \mathrm{dj}$ & $* \mathrm{di}$ & IDENT-STRI \\
\hline$[\mathrm{adja}]$ & & & $* !$ & & \\
\hline \hline$[\mathrm{adzja}]$ & & & & & $*$ \\
\hline
\end{tabular}

(36) /adia/ in Type A languages:

a.

\begin{tabular}{r||c|c:c|c|c|} 
/adia/ & $*{ }_{\mathrm{tj}}$ & $* \mathrm{ti}$ & $* \mathrm{dj}$ & $* \mathrm{di}$ & IDENT-STRI \\
\hline$[$ adia] & & & & $* !$ & \\
\hline$[$ adzia] & & & & & $*$ \\
\hline
\end{tabular}

In these tableaux it can be observed that all four markedness constraints outrank the one faith constraint.

The occurring language types posited above in (7) are summarized in (37) with a corresponding example. In (38) we have repeated from (8) the nonoccurring language types.

$\begin{array}{llll} & \begin{array}{l}\text { Occurring assibilation types: } \\ \text { assibilating segment }(s)\end{array} & \text { trigger }(s) & \text { example } \\ \mathrm{A} & / \mathrm{t} \mathrm{d} / & / \mathrm{i} \mathrm{j} / & \text { Quebec French } \\ \mathrm{B} & / \mathrm{t} \mathrm{d} / & / \mathrm{j} / & \text { Romanian } \\ \mathrm{C} & / \mathrm{t} / & / \mathrm{i} \mathrm{j} / & \text { Hittite } \\ \mathrm{D} & / \mathrm{t} / & / \mathrm{j} / & \text { Latin } \\ \mathrm{E} & \text { none } & \text { none } & \text { Nhanda }\end{array}$

Nonoccurring assibilation types: assibilating segment(s)

$\begin{array}{lll}\mathrm{F} & / \mathrm{t} \mathrm{d} / & / \mathrm{i} / \\ \mathrm{G} & / \mathrm{t} / & / \mathrm{i} / \\ \mathrm{H} & / \mathrm{d} / & / \mathrm{i} j / \\ \mathrm{I} & / \mathrm{d} / & / \mathrm{j} / \\ \mathrm{J} & / \mathrm{d} / & / \mathrm{i} /\end{array}$

The universal hierarchy in (30) together with the faith constraint IDENT-[STRID] yield six rankings, five of which correspond to the occurring language types in (37). Here and below a non-ranking between the constraints in indicated with the curly brackets. ${ }^{11}$

(39) Language Type
a. Type A
b. Type B
c. Type C
d. Type D
e. Type E

\section{Ranking}

$* \mathrm{tj} \gg\{* \mathrm{ti}, * \mathrm{dj}\} » * \mathrm{di} \gg$ IDENT-STRI

$* \mathrm{tj} » * \mathrm{dj} »$ IDENT-STRI $\gg * \mathrm{ti} » * \mathrm{di}$

$* \mathrm{tj} \gg * \mathrm{ti} \gg$ IDENT-STRI $\gg * \mathrm{dj} » * \mathrm{di}$

$* \mathrm{tj} \gg$ IDENT-STRI $\gg\{* \mathrm{ti}, * \mathrm{dj}\} » * \mathrm{di}$

IDENT-STRI $» * \mathrm{tj} »\{* \mathrm{ti}, * \mathrm{dj}\} » * \mathrm{di}$

The sixth logically possible language type is the ranking * $\mathrm{tj} »\{* \mathrm{ti}, * \mathrm{dj}\} »$ IDENT-STRI $» * \mathrm{di}$. This language type is discussed in $\S 4.3$ below, where we show that it is in fact attested.

11 Technically speaking a 'non-ranking' between two constraints implies two separate rankings, e.g. for Type A in (39a) two rankings:

(i) $* \mathrm{tj} \gg *$ ti $» * \mathrm{dj} » * \mathrm{di} »$ IDENT-STRI

$* \mathrm{tj} \gg * \mathrm{dj} \gg *$ ti $» * \mathrm{di} »$ IDENT-STRI

Importantly, both rankings in (i) yield the same effect. 
The five language types in (37) do not occur because they would require rankings that are not in harmony with the universal rankings in (30). This point is made clear in (40):

(40) Nonoccurring language types:

Language Type Illicit Ranking
a. Type F
$\{* \mathrm{ti}, * \mathrm{di}\} »$ IDENT-STRI $\gg\{* \mathrm{t} \mathrm{j}, * \mathrm{dj}\}$
b. Type $\mathrm{G}$
$*$ ti $\gg$ IDENT-STRI $\gg\{* \mathrm{tj}, * \mathrm{dj}, * \mathrm{di}\}$
c. Type $\mathrm{H}$
$\left\{* \mathrm{dj},{ }^{*} \mathrm{di}\right\} \gg$ IDENT-STRI $\gg\left\{* \mathrm{ti}, *^{*} \mathrm{j}\right\}$
d. Type I
$* \mathrm{dj} \gg$ IDENT-STRI $\gg\{* \mathrm{ti}, * \mathrm{tj}, * \mathrm{di}\}$
e. Type J
$*$ di » IDENT-STRI » $\{* \mathrm{ti}, * \mathrm{tj}, * \mathrm{dj}\}$

An examination of the rankings in (40) reveals that they all violate at least one of the universal rankings in (30). Thus, Type $\mathrm{F}$ requires (by transitivity) that $\{* \mathrm{ti}, * \mathrm{di}\}$ outrank $\{* \mathrm{tj}$, $* \mathrm{dj}\}$ and Type $\mathrm{G}$ that *ti outrank *tj. Types H-J are nonoccurring because they would require $*$ dj and/or *di to outrank *tj and/or *ti.

\subsection{Additional language types}

As noted in $\S 4.2$ above the constraints posited predict a sixth language type, which we refer to below as Type E':
Language Type
(41) Type E'
Ranking
$* \mathrm{tj} \gg\{* \mathrm{ti}, * \mathrm{dj}\} »$ IDENT-STRI $» * \mathrm{di}$
Effect
$\mathrm{t}, \mathrm{d}$ assibilate before $\mathrm{j}$;
$\mathrm{t}$ assibilates before $\mathrm{i}$

In the final column of (41) it can be seen that the ranking for Type E' describes a 'mixed' system in the sense that it captures two separate processes, namely one which assibilates $/ \mathrm{t} d /$ before $/ j /$ and the other which assibilates $/ t /$ before $/ \mathrm{i} /$. In this respect Type $E$ ' is very different from Types A-D, which all describe a single process each. Note that Type $E^{\prime}$ is essentially a Type B language which also has a process assibilating / $/$ / before $/ \mathrm{i} /$. We are aware of only one Type E' language, namely English (see below); however, we speculate that additional examples might be found among the Type B languages.

The English examples in (42a) illustrate that $/ \mathrm{t} d /$ surface as $[\mathrm{t} \square \mathrm{d}[\mathrm{b}$ before $/ \mathrm{j} /$-initial suffixes and the ones in (42b) that the same kind of process takes place across words (especially before the words you and your) in casual speech. ${ }^{12}$ Importantly, neither of the two processes in (42a-b) goes into effect before a morpheme beginning with a high front vowel, e.g. wha[t] if, * wha[t] if.

Assibilation in English:
a. perpe[t]]ual
resi[dD]ual
(cf. perpe[t]uity)
(cf. resi[d]ue)
b. wha[t] you
ha[d] you
c. democra[t]
presiden $[\mathrm{t}]$
$\operatorname{vacan}[\mathrm{t}]$
democra[s]y
presiden[s]y
$\operatorname{vacan}[\mathrm{s}] \mathrm{y}$

\footnotetext{
12 We follow tradition in English phonology in assuming that the suffixes in examples like the ones in (42a) are $/ \mathrm{j}$--initial, even though this segment does not surface in many dialects. It should also be noted that the process in (42a) only affects foot-internal $/ \mathrm{t} d /$, since these segments are not palatalized before a $/ \mathrm{j} /$-initial suffix which begins a foot, e.g. the underlined $t$ in perpetuity (see Borowsky 1986).
} 
Besides the palatalization process in (42a-b), English has a separate process which assibilates $/ \mathrm{t} /$ to $[\mathrm{s}$ ] before /i/. Several alternating pairs have been listed in (42c) which motivate this process. Importantly, the process in (42c) does not affect [d], e.g. jaggedy, raggedy.

In addition to the language type in (41), there are five further examples of mixed languages, but in contrast to Type E', these five additional mixed types are all nonoccurring. The additional nonoccuring language types are listed below in (43).

\begin{tabular}{|c|c|c|c|}
\hline \multicolumn{2}{|c|}{$\begin{array}{l}\text { assibilating segment(s) } \\
\text { astong }\end{array}$} & trigger(s) & Illicit ranking required \\
\hline a. & $/ \mathrm{t} /$ & $/ \mathrm{i} \mathrm{j} /$ & $\{* \mathrm{tj}, * \mathrm{ti}, * \mathrm{di}\} »$ IDENT-STRI $\gg * \mathrm{dj}$ \\
\hline & $/ \mathrm{d} /$ & /i/ & \\
\hline b. & $/ \mathrm{t} /$ & /i/ & $\{* \mathrm{ti}, * \mathrm{di}, * \mathrm{dj}\} »$ IDENT-STRI $\gg * \mathrm{tj}$ \\
\hline & $/ \mathrm{d} /$ & $/ \mathrm{i} \mathrm{j} /$ & \\
\hline c. & $/ \mathrm{t} /$ & /i/ & $\{* \mathrm{ti}, * \mathrm{dj}\} »$ IDENT-STRI $\gg\{* \mathrm{tj}, * \mathrm{di}\}$ \\
\hline & $/ \mathrm{d} /$ & $/ \mathrm{j} /$ & \\
\hline d. & $/ \mathrm{t} /$ & $/ \mathrm{j} /$ & $\{* \mathrm{tj}, * \mathrm{di}, * \mathrm{dj}\} »$ IDENT-STRI $\gg * \mathrm{ti}$ \\
\hline & $/ \mathrm{d} /$ & $/ \mathrm{i} \mathrm{j} /$ & \\
\hline & $/ \mathrm{t} /$ & $/ \mathrm{j} /$ & $\{* \mathrm{tj}, * \mathrm{di}\} \gg$ IDENT-STRI $\gg\{* \mathrm{ti}, * \mathrm{dj}\}$ \\
\hline & $/ \mathrm{d} /$ & $/ \mathrm{i} /$ & \\
\hline
\end{tabular}

As was the case in (40) each of the additional language types in (43) is nonoccurring because it would violate the universal constraint rankings in (30). Thus, the ranking $\left\{{ }^{\mathrm{t} j},{ }^{*} \mathrm{ti},{ }^{*} \mathrm{di}\right\} »$ $* \mathrm{dj}$ in $(43 \mathrm{a})$ violates the universal ranking $* \mathrm{dj} » * \mathrm{di}$ and in $(43 \mathrm{~b}, \mathrm{c}) * \mathrm{ti} \gg * \mathrm{tj}$ is the opposite of the proposed ranking *tj $" *$ ti. The ranking in $(43 \mathrm{~d})$ requires $*$ di to be ahead of $* \mathrm{ti}$, but it was argued above that $* \mathrm{ti} \gg *$ di is universal. Finally, $(43 \mathrm{e})$ requires $*$ di to outrank $* \mathrm{dj}$.

\section{$1.4 \quad$ Frequency}

As noted above in $\S 4.1$ the distribution among the six occurring language types is not equal, since many languages fall into the $\mathrm{A}, \mathrm{C}$ and $\mathrm{E}$ category, and only a few in $\mathrm{B}, \mathrm{D}$ and $\mathrm{E}^{\prime}$ each. What is more, Type $\mathrm{C}$ appears to be more common than Type A and Type E. We hypothesize that these proportions are not due to chance and therefore propose an explanation below.

We argue here that the unequal distribution among language types - in particular the cross-linguistic preference of $\{A, C, E\}$ over $\{B, D, E '\}$ - can be accounted for by considering whether or not the natural class of vowels and glides (i.e. [i j]) is captured by the markedness constraints. When the constraints *ti and $* \mathrm{tj}$ (as well as $* \mathrm{di}$ and $* \mathrm{dj}$ ) are ranked together above or below the one faith constraint then we see this as evidence that $[\mathrm{i} j]$ function together as a unit. By contrast, if $* \mathrm{ti}$ and $* \mathrm{tj}$ (as well as $* \mathrm{di}$ and $* \mathrm{dj}$ ) are ranked on opposite sides of faith then this means that [ $\mathrm{i} j]$ do not function together as a natural class. This point can be illustrated with each of the six occurring language types in (39) and (41) to determine whether or not the natural class [i j] is respected. This is shown in (44), where we list each of the six occurring language types in the first column. In the second column '+' or '-' indicates whether or not the respective language respects or does not respect the natural class [ $\mathrm{i}$ j] (which we symbolize here as ' $\mathrm{i} / \mathrm{j}$ ').

$\begin{array}{ll}\text { Language Type } & \\ \text { Type A } & + \\ \text { Type B } & - \\ \text { Type C } & + \\ \text { Type D } & - \\ \text { Type E } & + \\ \text { Type E' } & -\end{array}$


The table in (44) indicates that Types A, C and E are the three language types in which the natural class $[\mathrm{i} j]$ is respected and that Types $B, D$ and E'are the three where $[\mathrm{i} j]$ are not treated as a class. The lower frequency of Type B, D, and E' languages can therefore be interpreted as a consequence of the tendency in the languages of the world to treat [ $\mathrm{i}]$ as a unit. That this natural class is important is substantiated by the fact that [i] and [j] are virtually the same sound from the point of view of articulatory phonetics (recall the discussion in $\S 4.1$ above). In addition, many linguists have shown that [i] and [j] are positional variants in various languages, suggesting that these two sounds are - at least in the unmarked case - one at the underlying level.

A second generalization concerning frequency is that within the $\mathrm{A} / \mathrm{C} / \mathrm{E}$ category languages of Type A and Type $\mathrm{E}$ seem to be more common than those belonging to Type $\mathrm{C}$. This generalization can be expressed by considering the natural class of $/ \mathrm{t} d /$ (represented as ' $\mathrm{t} / \mathrm{d}$ ' below), which would be satisfied if the constraints $* \mathrm{ti}$ and $* \mathrm{di}$ (as well as $* \mathrm{tj}$ and $* \mathrm{dj}$ ) are ranked together with respect to the faith constraint. An examination of the rankings for Type A and Type E reveals that both of these languages satisfy the $t / d$ natural class but this is not the case with Type $\mathrm{C}$.

To summarize, the six occurring language types can be arranged in a harmonic scale, which corresponds to frequency. (See Prince \& Smolensky 1993, who argue that markedness relation for segment types can be arranged in a scalar fashion, e.g. COR » LAB, which says that coronal is less marked than labial. Note that markedness in this sense is also often correlated with cross-linguistic frequency).

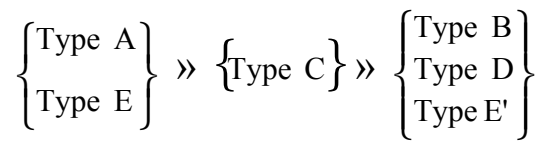

What this scale says is that Type A and Type E are the most harmonic assibilation types, which we interpret to mean that they are the most common ones in the languages of the world. We hypothesize that given a large enough sample of assibilations Type A and Type E will predominate over the other types. Based on our typology Type $\mathrm{C}$ is slightly less common than Type A and Type E but much more common than Type B, Type D and Type E'. Again, only future research can (dis)confirm the cross-linguistic predictions made by the hierarchy in (45).

\section{Conclusion}

In this article we proposed two new universal properties for assibilation rules and presented typological evidence from assibilations in 45 languages supporting them. We argued that assibilations are to be captured in the OT framework by ranking markedness constraints grounded in perception which penalize sequences like [ti] ahead of a faith constraint which militates against the change from /t/ to some sibilant sound. The six occurring language types were shown to involve permutations of the rankings between several different markedness constraints and the one faith constraint. The article demonstrated that there exist several logically possible assibilation types which are ruled out because they would involve illicit rankings. 


\section{Appendix}

\begin{tabular}{|c|c|c|c|}
\hline Language & Family & Geographical area & Source \\
\hline 'Ala'ala & Austronesian (Oceanic) & Papua New Guinea & Lynch, Ross \& Crowley (2002) \\
\hline Albanian & Indo-European (Albanian) & Albania & Buchholz \& Fiedler (1987) \\
\hline Ambae & Austronesian (Oceanic) & Vanuatu (Ambae islands) & Hyslop (2001) \\
\hline Apalai & Carib & Brazil (Paru Leste River) & Koehn \& Koehn (1986) \\
\hline Arosi & Austronesian (Oceanic) & Solomon Islands & Lynch, Ross \& Crowley (2002) \\
\hline Axininca Campa & Arawakan & Peru (Pachitea River) & Spring (1992) \\
\hline Blackfoot & Algic (Plains) & Canada (Alberta) & Frantz (1991) \\
\hline Chamorro & Austronesian & Guam & Topping (1973) \\
\hline Cheyenne & Algic (Plains) & USA (Montana) & Davis (1962) \\
\hline Danish & Indo-European (Germ.) & Denmark & BasbDll \& Wagner (1985) \\
\hline Dutch & Indo-European (Germ.) & The Netherlands & Booij (1995) \\
\hline English & Indo-European (Germ.) & United Kingdom etc. & Luick (1921) \\
\hline Finnish & Uralic (Finno-Ugric) & Finland & Kiparsky (1973) \\
\hline Gaagudju & Australian & Australia & Harvey (2002) \\
\hline Gbe (Ewe) & Niger-Congo (Bantu) & & \\
\hline -Kpándo (Vhe) dialect & & Ghana & Capo (1991) \\
\hline -Fongbe dialect & & Benin & Lefebre \& Brousseau (2002) \\
\hline German & Indo-European (Germ.) & Germany & Hall (2003), Penzl (1972) \\
\hline Greek (Ancient) & Indo-European (Hellenic) & extinct & Sommerstein (1973) \\
\hline Greenlandic (West) & Eskimo-Aleut & Greenland & Fortescue (1984) \\
\hline Hittite & Indo-European & extinct & Kimball (1999) \\
\hline Humburi Senni & Nilo-Saharan (Songhay) & Mali & Heath (1999) \\
\hline Italian & Indo-European (Romance) & Italy & Tuttle (1997), Cordin (1997) \\
\hline Japanese & isolate & Japan & Ito \& Mester (1995) \\
\hline Kashmiri & Indo-European (Indo-Iran.) & India & Wali \& Koul (1997) \\
\hline Kinyamwezi & Niger-Congo (Bantu) & Tanzania & Magana \& Schadeberg (1992) \\
\hline Korean & isolate & South Korea & $\operatorname{Kim}(2001)$ \\
\hline Kosraean & Austronesian (Oceanic) & Caroline islands & Lee \& Wang (1984) \\
\hline Koyra Chiini & Nilo-Saharan (Songhay) & Mali & Heath (1999) \\
\hline Lahu & Tibeto-Burman & Thailand & Matisoff (1982) \\
\hline Latin & Indo-European (Italic) & extinct & Pope (1952), Sommer (1948) \\
\hline Latvian & Indo-European (Baltic) & Latvia & Forssman (2001) \\
\hline Maori & Austronesian (Oceanic) & New Zealand & Bauer (1993) \\
\hline Mongo (Lomongo) & Niger-Congo (Bantu) & Congo & Spaandonck (1964) \\
\hline Nadroga (Fijian) & Austronesian (Oceanic) & Fiji & Lynch, Ross \& Crowley (2002) \\
\hline Nauruan & Austronesian (Oceanic) & Nauru & Kayser (1993) \\
\hline Nhanda & Australian & Australia & Blevins (2001) \\
\hline Nishnaabemwin (Ojibwe & e) Algic (Algonquian) & Canada (Ontario) & Valentine (2001) \\
\hline Nyakyusa & Niger-Congo (Bantu) & Tanzania & Labroussi (1999) \\
\hline Papago (O'odham) & Uto-Aztecan (Tempiman) & USA (Arizona) & Halle \& Clements (1983) \\
\hline Pima Bajo & Uto-Aztecan (Tempiman) & Mexico & Fernandez (1996) \\
\hline Plains Cree & Algic (Algonquian) & Canada & Wolfart (1973) \\
\hline Polish & Indo-European (Slavic) & Poland & Rubach (1994), Carlton (1990) \\
\hline Quebec French & Indo-European (Romance) & Quebec & Cedegren et al. (1991) \\
\hline Ririo & Austronesian (Oceanic) & Solomon Islands & Tryon \& Hackman (1983) \\
\hline Romanian & Indo-European (Romance) & Romania & Chitoran (2001) \\
\hline Rundi & Niger-Congo (Bantu) & Burundi & Spandoonck (1964) \\
\hline Runyoro-Rutooro & Niger-Congo (Bantu) & Uganda & Rubongoya (1999) \\
\hline Samoan & Austronesian (Oceanic) & Western Samoa & Mosel \& Hovdhaugen (1992) \\
\hline
\end{tabular}




\begin{tabular}{llll} 
Sanskrit & \multicolumn{2}{l}{ Indo-European (Indo-Aryan) extinct } & Misra (1967) \\
Sengga & Austronesian (Oceanic) & Solomon Islands & Tryon \& Hackman (1983) \\
Serbo-Croatian & Indo-European (Slavic) & former Yugoslavia & Kordicட1997) \\
Shona & Niger-Congo (Bantu) & Zimbabwe & Brauner (1995) \\
Slovak & Indo-European (Slavic) & Slovakia & Carlton (1990) \\
Sonora Yaqui & Uto-Aztecan (Sonoran) & Mexico (Sonora) & Dedrick \& Casad (1999) \\
Sorbian & Indo-European (Slavic) & Germany & WowcErk (1954) \\
Southern Kongo & Niger-Congo (Bantu) & Angola & Halle \& Clements (1983) \\
Taiof (Saposa) & Austronesian (Oceanic) & Papua New Guinea & Lynch, Ross \& Crowley (2002) \\
Tawala & Austronesian (Oceanic) & Papua New Guinea & Ezard (1997) \\
Tümpisa Shoshone & Uto-Aztecan (Numic) & USA (California) & Dayley (1989) \\
Turkana & Nilo-Saharan & Kenya & Dimmendaal (1983) \\
Vaghua & Austronesian (Oceanic) & Solomon Islands & Tryon \& Hackman (1983) \\
Varisi & Austronesian (Oceanic) & Solomon Islands & Tryon \& Hackman (1983) \\
Wai Wai & Carib (Northern) & Brazil & Hawkins (1998) \\
West Futuna-Aniwa & Austronesian (Oceanic) & Vanuatu (Futuna Islands) & Dougherty (1983) \\
Woleaian & Austronesian (Oceanic) & Caroline islands & Tawerilmang \& Sohn (1984)
\end{tabular}




\section{References}

Basbl11, H. \& J. Wagner 1985. Kontrastive Phonologie des Deutschen und Dänischen: Segmentale Wortphonologie und -phonetik. Tübingen: Niemeyer.

Bauer, W. 1993. Maori. London: Routledge.

Bhat, D. N. S. 1978. A general study of palatalisation. In: J. Greenberg et al. (eds.) Universals of human language. Stanford: Stanford University Press; 47-92.

Blevins, J. 2001. Nhanda: An Aboriginal Language of Western Australia. Honolulu: University of Hawaii Press.

Boersma, P. 1998. Functional Phonology: Formalizing the Interaction Between Articulatory and Perceptual Drives. The Hague: Holland Academic Graphics.

Booij, G. 1995. The phonology of Dutch. Oxford: Clarendon Press.

Borowsky, T. 1986. Topics in the lexical phonology of English. Ph.D. dissertation, University of Massachusetts at Amherst. [Published 1990. New York: Garland.]

Brauner, S. 1995. A grammatical sketch of Shona: including historical notes. Köln: Köppe.

Buchholz, O. \& W. Fiedler 1987. Albanische Grammatik. Leipzig: VEB Verlag Enzyklopädie.

Capo, H. B. C. 1991. A comparative phonology of Gbe. Dordrecht: Foris.

Carlton, T. R. 1990. Introduction to the phonological history of the Slavic languages. Columbus: Slavica.

Catford, J. C. 2001. A practical introduction to Phonetics. Oxford: Oxford University Press. [Second edition.]

Cedegren, H. J., J. D. Archambault \& G. Boulianne 1991. Stop assibilation in Quebec French: an analysis by articulatory synthesis. Proceedings of the $12^{\text {th }}$ international congress of phonetic sciences. Vol. 3. Aix-enProvence ; 186-189.

Chitoran, I. 2001. The phonology of Romanian: a constraint-based approach. Berlin: Mouton.

Chomsky, N. \& M. Halle. 1968. The sound pattern of English. New York: Harper \& Row.

Clements, G. N. 1999. Affricates as noncontoured stops. In: O. Fujimura et al. (eds.) Item, order in language and speech. Prague: Charles University Press, 271-299.

Cordin, P. 1997. Trentino. In: M. Maiden \& M. M. Parry (eds.) The dialects of Italy. London: Routledge; 260262.

Davis, I. 1962. Phonological function in Cheyenne. International Journal of American Linguistics 28.1: 36-42.

Dayley, J. P. 1989. Tümpisa (Panamint) Shoshone grammar. Berkeley: Univ. of California Press.

Dedrick, J. M. \& E. H. Casad. 1999. Sonora Yaqui Language Structures. Tucson: University of Arizona Press.

Dimmendaal, G. J. 1983. The Turkana Language. Dordrecht: Foris.

Dixon, R. M. W. 1980. Languages of Australia. Cambridge: Cambridge University Press.

Dougherty, J. W. D. 1983. West Futuna-Aniwa: An Introduction to a Polynesian Outlier Language. Berkeley: University of California Press.

Ebermann, E. 1986. Die Sprache der Mauka. Wien: VWGÖ.

Ezard, B. 1997. A grammar of Tawala. Canberra: Pacific Linguistics.

Fernandez,ZZ. E. 1996. Pima Bajo. München: Lincom.

Flemming, E. 1995. Auditory representations in phonology. Ph.D. dissertation, UCLA. [Published 2002. New York: Garland.]

Foley, J. 1973. Assibilation as universal phonological rule. Folia Linguistica 6 (3-4): 251-262.

Foley, J. 1977. Foundations of Theoretical Phonology. Cambridge: Cambridge University Press.

Forssman, B. 2001. Lettische Grammatik. München: Röll.

Fortescue, M. 1984. West Greenlandic. London: Croom Helm.

Frantz, D. 1991. Blackfoot Grammar. Toronto: University of Toronto Press.

Hale, K. 1965. Some preliminary observations on Papago morphophonemics. International Journal of American Linguistics 31: 295-305.

Hall, T. A. 2003. Assibilation in Modern German. To appear in Lingua.

Halle, M. \& G. N. Clements. 1983. Problem book in phonology. Cambridge, Mass.: MIT Press.

Hamann, S. 2003. The Phonetics and Phonology of Retroflexes. Utrecht: LOT Press. 
Harvey, M. 2002. A Grammar of Gaagudju. Berlin: Mouton.

Hawkins, R. 1998. Wai Wai. D. Derbyshire \& G. Pullum (eds.) Handbook of the Amazonian languages: Volume 4. Berlin: Mouton de Gruyter; 25-224.

Heath, J. 1999. A grammar of Koyraboro. Köln: Köppe.

Hualde, J. I. 1991. Basque Phonology. London: Routledge.

Hyslop, C. 2001. The Lolovoli dialect of the North-East Ambae language, Vanuatu. Canberra: Pacific Linguistics.

Ingham, B. 1994. Najdi Arabic: Central Arabian. Amsterdam: Benjamins.

Ito, J. \& A. Mester. 1995. “Japanese Phonology.” In J. Goldsmith (ed.) The handbook of phonological theory. Cambridge, Mass.: Blackwell; 817-838.

Jacobs, H. 1989. Nonlinear studies in the historical phonology of French. Dissertation, University of Nijmegen.

Jakobson, R., G. Fant and M. Halle. 1952. Preliminaries to speech analysis: The distinctive features and their correlates. Cambridge: MIT Press.

Jensen, C.1998. Comparative TupiĐGuarani[Morphosyntax. In: D. Derbyshire \& G. Pullum (eds.) Handbook of the Amazonian languages: Volume 4. Berlin: Mouton de Gruyter; 489-618.

Jensen, C. 1999. TupiĐGuarani] In: R.M.W. Dixon \& A. Aikhenvald (eds.) The Amazonian languages. Cambridge: Cambridge University Press; pp. 125-164.

Kayser, A. 1993. Nauru Grammar. Canberra: Australian national University. [ed. by K. H. Rensch]

Kehrein, W. 2002. Phonological representation and phonetic phrasing: affricates and laryngeals. Tübingen: Niemeyer.

Kim, H. 2001. A phonetically based account of phonological stop assibilation. Phonology 18: 81-108.

Kimball, S. E. 1999. Hittite Historical Phonology. Innsbruck: Innsbrucker Beiträge zur Sprachwissenschaft.

Kiparsky, P. 1973. Abstractness, opacity and global rules. In: O. Fujimura (ed.) Three dimensions of linguistic theory. Tokio: Taikusha; 57-86.

Kirchner, R. M. 1998. An Effort-Based Approach to Consonant Lenition. Ph.D. dissertation: UCLA.

Koehn, E. \& S. Koehn. 1986. Apalai. D. Derbyshire \& G. Pullum (eds.) Handbook of the Amazonian languages: Volume 1. Berlin: Mouton de Gruyter; 33-127.

Kordic ЏS. 1997. Serbo-Croatian. Muenchen: Lincom.

Labroussi, C. 1999. Vowel systems and spirantization in Southwest Tanzania. In: J.-M. Hombert \& L. Hyman (eds.) Bantu Historical Linguistics. Stanford: CSLI publications ; 335-377.

LaCharité, D. 1993. The internal structure of affricates. Ph.D. dissertation, University of Ottawa.

Lee, K.-D. \& J. W. Wang. 1984. Kosraean reflexes of Proto-Oceanic phonemes. In: B. W. Bender (ed) Studies in Micronesian Linguistics. Pacific Linguistics Series C-No. 80. Canberra: The Australian National University; 403-442.

Lefebre, C. \& A.-M. Brousseau. 2002. A Grammar of Fongbe. Berlin: Mouton de Gruyter.

Luick, K. 1921. Historische Grammatik der englischen Sprache. Leipzig: Tauchnitz.

Lynch, J., M. Ross \& T. Crowley. 2002. The Oceanic languages. Richmond: Curzon.

Magana, C. \& T. C. Schadeberg. 1992. Kinyamwezi: Grammar, texts, vocabulary. Köln: Köppe.

Matisoff, J. A. 1982. The Grammar of Lahu. Berkeley: University of California Press.

Merlan, F. 1989. Mangarayi. London: Routledge.

Misra, B. G. 1967. Historical phonology of Modern Standards Hindi. Ph.D. dissertation: Cornell University.

Mosel, U. \& E. Hovdhaugen 1992. Samoan Reference Grammar. Oslo: Scandinavian University Press.

Nordlinger, R. 1998. A grammar of Wambaya, Northern territory. Canberra: Australian National University.

Ohala, J. 1983. The origin of sound patterns in vocal tract constraints. In: P. MacNeilage (ed.) The production of speech. New York: Springer; 189-216.

Penzl, H. 1972. Methoden der germanistischen Linguistik. Tübingen: Niemeyer.

Pope, M. K. 1952. From Latin to Modern French with special consideration of Anglo-Norman. Phonology and morphology. Manchester: Manchester University Press.

Posti, L. 1954. From pre-Finnic to Late Proto-Finnic: studies on the development of the consonant system. Finnisch-Ugrische Forschungen 31: 1 -91.

Prince, A. \& P. Smolensky. 1993. Optimality Theory. Ms., Rutgers University and University of Colorado. 
Rubach, J. 1993. The Lexical Phonology of Slovak. Oxford: Clarendon.

Rubach, J. 1994. Affricates as strident stops in Polish. Linguistic Inquiry 25: 119-143.

Rubongoya, L.T. 1999. A Modern Runyoro-Rutooro Grammar. Köln: Köppe.

Sommer, F. 1948. Handbuch der Lateinischen Laut- und Formenlehre. Heidelberg: Winter.

Sommerstein, A. H. 1973. The Sound Pattern of Ancient Greek. Oxford: Blackwell.

Spandoonck, M.V. 1964. Palatalization: a phonological process in Bushoong. Journal of African languages 3,2: 191-201.

Spring, C. 1992. The velar glide in Axininca Campa. Phonology 9.2: 329-352.

Steriade, D. 2001. Directional asymmetries in place assimilation: a perceptual account. In: E. Hume \& K. Johnson (eds.) Phonology: The Role of Speech Perception in Phonology. San Diego (CA): Academic Press; 219-250.

Sulkala, H. \& M. Karjalainen. 1992. Finnish. London: Routledge

Tawerilmang, A. F. \& H.-M. Sohn. 1984. Proto-Oceanic reflexes in Woleaian. In: B. W. Bender (ed.) Studies in Micronesian Linguistics. Pacific Linguistics Series C-No. 80. Canberra: The Australian National University; 171-199.

Topping, D. M. 1973. Chamorro reference Grammar. Honolulu: University of Hawaii Press.

Tryon, D. T. \& B. D. Hackman. 1983. Solomon Island Languages: An Internal Classification. Pacific Linguistics Series C-No. 72.

Tuttle, E. 1997. Palatalization. In: M. Maiden \& M. M. Parry (eds.) The dialects of Italy. London: Routledge; 2631.

Valentine, R. 2001. Nishnaabemwin Reference Grammar. Toronto: University of Toronto Press.

Wali, K. \& O. Koul 1997. Kashmiri. London: Routledge.

Wolfart, H. C. 1973. Plains Cree: A Grammatical Study. Philadelphia: The Americal Philosophical Society.

WowcBrk, P. 1954. Kurzgefasste Obersorbische Grammatik. Phonetik und Morphologie. Berlin: Volk und Wissen. 